BlACK, K. (2006): Business Statistics: For Contemporary Decision Making, $4^{\text {th }}$ Edition. John Willey and Sons, Hoboken.

Bonner, F. T., J. A. Vozzo, W. W. Elam and S. B. LAND JR (1994): Tree Seed Technology Training Course. United States Department of Agriculture. New Orleans.

Escudero, A., F. PÉrez-García and A. L. Luzuriaga (2002): Effects of light, temperature and population variability on the germination of seven Spanish pines. Seed Science Research 12: 261-271.

Gonzales, J. L. S., S. V. VAleri and R. C. D. Paula (2011): Seed physiological quality of different Corymbia citriodora (Hook.) K. D. Hill \& L.A.S. Johnson mother trees. Scientia Forestalis 90: 171-178.

Hampton, J. G. and D. M. TeKrony (1995): Handbook of Vigour Test Methods, $3^{\text {rd }}$ edition. The International Seed Testing Association. Zurich.

Krugman, S. L. and J. L. Jenkinson (2008): Pinus L., pp. 809-847. In: The woody plant seed manual, edited by Bonner, F. T. and R. P. KARRFAlt, Agriculture Handbook 727, USDA Forest Service, United States.
Pekşen, E., A. Pekşen, H. Božoglu and A. Gülümser (2004): Some seed traits and their relationship to seed germination and field emergence in pea (Pisum sativum L.). Journal of Agronomy 3(4): 243-246.

SAHLÉN, K. and S. GJELSVIK (1993): Determination of Pinus sylvestris seed maturity using leachate conductivity measurements. Canadian Journal of Forest Research 23(5): 864-870.

SǿRensen, A., E. B. LAURIDSEN and K. Thomsen (1996): Electrical conductivity test. Technical Note No. 45. Danida Forest Seed Centre, Denmark.

YounG, J. A and CH. G. Young (1992): Seeds of Woody Plants in North America. Dioscorides Press, Portland, Oregon.

ZHAO, G. and T. ZHONG (2012): Improving the assessment method of seed vigor in Cunninghamia lanceolata and Pinus massoniana based on oxygen sensing technology. Journal of Forestry Research 23(1): 95-101.

\title{
Provenance Variation in Radial Increment and Wood Characteristics Revealed by 30 Years Old Norway Spruce Comparative Trials
}

\author{
By N. ŞofleteA ${ }^{1)}$, M. Budeanu ${ }^{2)}$ and G. PÂRnuţă $\check{A}^{3)}$
}

(Received $31^{\text {th }}$ January 2012)

\begin{abstract}
The performance of 33 Norway spruce [Picea abies (L.) Karst.] seed sources from the Romanian Carpathians was evaluated with respect to growth and wood characteristics in comparative trials located at two different site conditions: Avrig- outside of the natural range of Norway spruce and Breţcu - within the natural range of this species. The radial increment (RI), latewood percentage (LWP) and conventional wood density (CWD) traits were evaluated at age 30 years after plantation. Phenotypic correlations between the evaluated traits, on the one hand, and between the same traits and the geographic gradients of the origin of seed sources, on the other hand, were calculated. Analysis of variance showed significant $(p<0.01)$ differences between seed sources for RI, while for LWP and CWD, the differences were highly significant $(\mathrm{p}<0.001)$. These results suggest that selection at seed sources level could be possible. The test sites influence the LWP and CWD, while the RI is almost similar in both sites. For RI, the most valuable

1) Dept. of Silviculture, Transilvania University of Braşov, Şirul Beethoven street, nr. 1, 500123, Braşov, Romania.

2) Corresponding author: MARIUS BUdEANU. Forest Research and Management Institute, Braşov Station, Cloşca street, nr. 13, 500040, Braşov, Romania. Phone: +040 268419936, Fax: +040 268415338. E-Mail: budeanumarius@yahoo.com.

$\left.{ }^{3}\right)$ Forest Research and Management Institute Bucharest, Eroilor Boulevard, nr. 128, 077190, Voluntari, Ilfov, Romania.
\end{abstract}

populations are situated in the Eastern and Western Romanian Carpathians. The highest LWP was registered for the Eastern Carpathian populations, while the lowest was recorded for the Western Carpathian populations. The Southern Carpathian populations, characterized by a lower growth rate, had higher values for wood density.

Key words: Picea abies, radial increment, latewood, wood density, seed sources, comparative trials.

\section{Introduction}

Norway spruce [Picea abies (L.) Karst.], the most important coniferous species in Europe, covers about 1.48 million ha in Romania (INS, 2011), which represents $77 \%$ of the coniferous forests and approximately $23.3 \%$ of the entire forest area. The stands are either pure, especially at medium and high altitudes, or mixed with European beech, silver fir, and Norway spruce situated at low and medium altitudes in the Carpathian Mountains (ŞOFLETEA and CURTU, 2007). Norway spruce has also been the main species used for the aforestation of non-forest lands in the last decades (IORAŞ and ABRUDAN, 2006; DUTCĂ et al., 2010). In Romania, the Norway spruce genetic resources are mostly preserved in situ; 89 gene conservation units were established, representing approximately $20 \%$ of the total forest conservation sur- 
face (PÂRNUŢĂ et al., 2011). Moreover, ex situ conservation in seed orchards (78.5 ha) and comparative progeny and provenances trials (37.5 ha) have been carried out. Therefore, the two comparative trials analyzed in the present paper simultaneously fulfill the objectives of conservation and of testing the genetic variability of 33 Norway spruce seed sources from the Romanian Carpathians.

Provenance tests have expanded a lot since the beginning of the twentieth century under the auspices of the International Union of Forest Research Organizations (IUFRO), leading to experiments being performed with provenance from many countries. The most comprehensive compilation regarding the Norway spruce provenance tests was made by evaluating the spatial pattern of genetic variation (KonIG, 2005). There have been three different series of Norway spruce experiments under the coordination of the IUFRO, including Romania: 1938/1939, 1964/1968 and 1972. All the data published from the trials of Bulgaria, Hungary, Poland, Romania, Scotland, Finland, Sweden and Norway, among others, indicate that the eastern Romanian provenances (e.g. Marginea and Moldoviţa) are one of the most valuable for Europe with regard to growth traits and adaptability (MATRAS, 1977; GIERTYCH, 1984, 1993; Alexandrov and Stancova, 1997; NAAPOla, 1997; KARLSSON and HOGBERG, 1998; SKROPPA, 2005; UJVARI and UJVARI, 2006; MiHAI, 2009).

The Avrig and Brețcu comparative trials belong to the multisite series of Romanian tests and were established in 1980. A phenotypic selection of the most valuable stands, designated as seed sources, in the natural area of the Norway spruce was first made, and then seed trees within the seed stand were selected during the establishments of these trials. The seedlings used germinated from open-pollinated seeds collected from seed trees. In these experimental trials, main objective was to evaluate the genetic variation to achieve a good management strategy in order to ensure the use of improved forest reproductive materials. This can be done by selecting the most valuable seed sources in each region, which is evaluated by recurrent selection criteria and compatible with the environmental conditions in the aforestation areas (PÂRNUŢĂ et al., 2010). This is a highly important requirement mentioned in many studies of forest genetics (KRUTZSCH, 1992; WHITE et al., 2007). This stage of research makes possible the transition from the untested seed sources, where the genetic status quo of the populations is preserved (ENESCU, 1996), to the "tested" category of forest reproductive materials, which offers much more guarantees for creating valuable stands for quantitative, qualitative and adaptation traits.

The objectives of the study were (i) to assess the variability of economically important quantitative traits by evaluating 33 open-pollinated seed sources from two provenance trials, (ii) to compare the test sites with respect to studied traits, (iii) to test the traits if they are expressed differently in two trial sites, and (iv) to analyze the correlations between traits and the influence of the ecological gradients.

\section{Materials and Methods}

Two comparative trials were established using seedlings obtained from bulked seeds harvested from 10 seed trees (ENESCU, 1996) identified in each of the 33 seed sources presented in Table 1. The seed sources will hereafter also be referred to as populations, indicating the local populations providing the forest reproductive materials.

The Avrig trial is located outside the Norway spruce's natural distribution range in the Romanian Carpathians, at an average altitude of $615 \mathrm{~m}, 45^{\circ} 39^{\prime} 36^{\prime \prime} \mathrm{N}$ lati-

Table 1. - Location and geographical coordinates of the tested populations (seed sources).

\begin{tabular}{|c|c|c|c|c|c|}
\hline Code & $\begin{array}{c}\text { Seed sources } \\
\text { (Region of provenance }^{*} \text { ) }\end{array}$ & $\begin{array}{c}\text { Altitude }[\mathrm{m}] / \\
\text { latitude }[\mathbf{N}] / \\
\text { longitude }[\mathrm{E}] /\end{array}$ & Code & $\begin{array}{c}\text { Seed sources } \\
\text { (Region of provenance) }\end{array}$ & $\begin{array}{c}\text { Altitude }[\mathbf{m}] / \\
\text { latitude }] \mathbf{N}] / \\
\text { longitude }[\mathbf{E}] /\end{array}$ \\
\hline 1 & Coşna (A2) & $1025 / 47^{\circ} 28^{\prime} / 25^{\circ} 10^{\prime}$ & 18 & Braşov (B1) & $1020 / 45^{\circ} 35^{\prime} / 25^{\circ} 35^{\prime}$ \\
\hline 2 & Dorna Candreni (A2) & $990 / 47^{\circ} 17^{\prime} / 25^{\circ} 05^{\prime}$ & 19 & Azuga (B2) & $1210 / 45^{\circ} 28^{\prime} / 25^{\circ} 40^{\prime}$ \\
\hline 3 & Frasin (A2) & $755 / 47^{\circ} 28^{\prime} / 25^{\circ} 48^{\prime}$ & 20 & Domnești (C2) & $650 / 45^{\circ} 11^{\prime} / 24^{\circ} 49^{\prime}$ \\
\hline 4 & Marginea (A2) & $670 / 47^{\circ} 49^{\prime} / 25^{\circ} 50^{\prime}$ & 21 & Orăştie (C1) & $680 / 45^{\circ} 43^{\prime} / 23^{\circ} 16^{\prime}$ \\
\hline 5 & Moldovița (A2) & $855 / 47^{\circ} 39^{\prime} / 25^{\circ} 34^{\prime}$ & 22 & Bistra $(\mathrm{C} 1)$ & $1350 / 45^{\circ} 35^{\prime} / 23^{\circ} 45^{\prime}$ \\
\hline 6 & Stulpicani (A2) & $985 / 47^{\circ} 22^{\prime} / 25^{\circ} 46^{\prime}$ & 23 & Voineasa (C2) & $1410 / 45^{\circ} 17^{\prime} / 23^{\circ} 55^{\prime}$ \\
\hline 7 & Năsăud (A1) & $1210 / 47^{\circ} 28^{\prime} / 24^{\circ} 25^{\prime}$ & 24 & Retezat (C1) & $970 / 45^{\circ} 27^{\prime} / 22^{\circ} 51^{\prime}$ \\
\hline 8 & Prundul Bârgăului (A1) & $1290 / 47^{\circ} 05^{\prime} / 24^{\circ} 45^{\prime}$ & 25 & Bozovici (D1) & $600 / 44^{\circ} 57^{\prime} / 21^{\circ} 59^{\prime}$ \\
\hline 9 & Rodna (A1) & $890 / 47^{\circ} 26^{\prime} / 24^{\circ} 50^{\prime}$ & 26 & Văliug (D1) & $940 / 45^{\circ} 12^{\prime} / 22^{\circ} 02^{\prime}$ \\
\hline 10 & Sânmartin (A3) & $900 / 46^{\circ} 13^{\prime} / 25^{\circ} 57^{\prime}$ & 27 & Beliş (E3) & $1210 / 46^{\circ} 32^{\prime} / 23^{\circ} 02^{\prime}$ \\
\hline 11 & Toplița (A3) & $910 / 46^{\circ} 45^{\prime} / 25^{\circ} 20^{\prime}$ & 28 & Turda (E3) & $1200 / 46^{\circ} 33^{\prime} / 23^{\circ} 02^{\prime}$ \\
\hline 12 & Gurghiu (A1) & $1225 / 46^{\circ} 45^{\prime} / 24^{\circ} 50^{\prime}$ & 29 & Beiuş (E2) & $520 / 46^{\circ} 52^{\prime} / 22^{\circ} 23^{\prime}$ \\
\hline 13 & Sovata (A1) & $1190 / 46^{\circ} 40^{\prime} / 25^{\circ} 05^{\prime}$ & 30 & Dobreşti (E2) & $510 / 46^{\circ} 53^{\prime} / 22^{\circ} 20^{\prime}$ \\
\hline 14 & Tarcău (A2) & $930 / 46^{\circ} 54^{\prime} / 26^{\circ} 06^{\prime}$ & 31 & Sudrigiu (E2) & $1050 / 46^{\circ} 31^{\prime} / 22^{\circ} 35^{\prime}$ \\
\hline 15 & Comandău (B1) & $1150 / 45^{\circ} 45^{\prime} / 26^{\circ} 20^{\prime}$ & 32 & Câmpeni (E3) & $1237 / 46^{\circ} 25^{\prime} / 23^{\circ} 10^{\prime}$ \\
\hline 16 & Nehoiu (B2) & $1120 / 45^{\circ} 37^{\prime} / 26^{\circ} 30^{\prime}$ & 33 & Gârda (E3) & $1295 / 46^{\circ} 29^{\prime} / 22^{\circ} 55^{\prime}$ \\
\hline 17 & Nehoiaşu (B2) & $1080 / 45^{\circ} 30^{\prime} / 26^{\circ} 10^{\prime}$ & & & \\
\hline
\end{tabular}

* Region of provenance established in Romania (PÂRNUŢă et al., 2010): A-Eastern Carpathians; B-Curved Carpathians; C-Southern Carpathians; D-Banat Mountains; E-Apuseni Mountains; $\mathrm{D}+\mathrm{E}=$ Western Carpathians. 
tude and $24^{\circ} 26^{\prime} 12^{\prime \prime}$ E longitude. The Bretcu trial was established in the ecologically optimum range of the species at an average altitude of $1000 \mathrm{~m}, 45^{\circ} 58^{\prime} 16^{\prime \prime} \mathrm{N}$ latitude and $26^{\circ} 24^{\prime} 12^{\prime \prime} \mathrm{E}$ longitude. In both comparative trials, the experimental design was a $6 \times 6$ incompletely balanced square grid design, with 3 replications and 49 seedlings per plot planted at 2 by $2 \mathrm{~m}$ spacing (Figure 1).

In each trial, 9 trees from each population (3 from every replication, belonging to the replication's mean diameter category) were chosen. The increment cores from these trees with Pressler borer were obtained at breast height $(1.30 \mathrm{~m})$, on the contour line for the Breţcu trial, where the land is slightly tilted, and along the north-south direction in the Avrig trial, where the land is relatively flat. The following characteristics were evaluated: $(i)$ the annual radial increments, their mean value and coefficient of variation; (ii) the periodical average increment that occurred every 5 years; (iii) the width of the earlywood and latewood and their average values; $(i v)$ the percentage of latewood from the width of

\begin{tabular}{|c|c|c|c|c|c|c|c|}
\hline 1 & 2 & 3 & 4 & 5 & 6 & \multirow{6}{*}{ 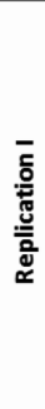 } & \multirow{3}{*}{$\begin{array}{llllllll}\mathrm{x} & \mathrm{x} & \mathrm{x} & \mathrm{x} & \mathrm{x} & \mathrm{x} & , \\
\mathrm{x} & \mathrm{x} & \mathrm{x} & \mathrm{x} & \mathrm{x} & \mathrm{x} & , \\
\mathrm{x} & \mathrm{x} & \mathrm{x} & \mathrm{x} & \mathrm{x} & \mathrm{x} & , \\
\mathrm{x} & \mathrm{x} & \mathrm{x} & \mathrm{x} & \mathrm{x} & \mathrm{x} & , \\
\mathrm{x} & \mathrm{x} & \mathrm{x} & \mathrm{x} & \mathrm{x} & \mathrm{x} & , \\
\mathrm{x} & \mathrm{x} & \mathrm{x} & \mathrm{x} & \mathrm{x} & \mathrm{x} & ,\end{array}$} \\
\hline 7 & 8 & 9 & 10 & 11 & 12 & & \\
\hline 13 & 14 & 15 & 16 & 17 & 18 & & \\
\hline 19 & 20 & 21 & 22 & 23 & 24 & & \\
\hline 25 & 26 & 27 & 28 & 29 & 30 & & \\
\hline 31 & 32 & 33 & 1 & 2 & 3 & & \\
\hline 1 & 7 & 13 & 19 & 25 & 31 & \multirow{6}{*}{ 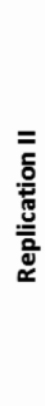 } & \\
\hline 2 & 8 & 14 & 20 & 26 & 32 & & \\
\hline 3 & 9 & 15 & 21 & 27 & 33 & & \\
\hline 4 & 10 & 16 & 22 & 28 & 1 & & \\
\hline 5 & 11 & 17 & 23 & 29 & 2 & & \\
\hline 6 & 12 & 18 & 24 & 30 & 3 & & \\
\hline 1 & 8 & 15 & 22 & 29 & 3 & \multirow{6}{*}{ 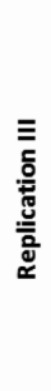 } & \\
\hline 31 & 2 & 9 & 16 & 23 & 30 & & \\
\hline 25 & 32 & 3 & 10 & 17 & 24 & & \\
\hline 19 & 26 & 33 & 4 & 11 & 18 & & \\
\hline 13 & 20 & 27 & 1 & 5 & 12 & & \\
\hline 7 & 14 & 21 & 28 & 2 & 6 & & \\
\hline
\end{tabular}

Figure 1. - Field arrangement of populations in both comparative trials.

Legend: $1,2 \ldots 33=$ Populations; $\mathrm{xxx}=$ trees in populations (49 bulked descendants in each population) planted at $2 \times 2 \mathrm{~m}$. 6 rows and 6 columns in each replications (experimental design: $6 \times 6)$. the annual rings; $(v)$ the percentage of latewood from the periodical average increment that occurred every 5 years; and (vi) conventional wood density.

To measure radial growth and the values of earlywood and latewood, a Rinntech LINTAB 5 tree-ring measurement station was used, while recordings and initial data processing were made using the TSAP Win software. This software facilitates the simultaneous recording of earlywood and latewood radial increments. The constructive features of the device allow core measurement with a standard resolution of 1:100, using a Leica stereomicroscope that provides an enlargement factor of $6: 1$ (BADEA, 2008).

To determine conventional wood density $\left(\rho_{c}\right)$, a method recommended by DUMITRIU-TĂTĂRANU et al. (1983) was used:

$$
\rho_{c}=\rho_{0} \frac{100}{100+\beta_{v}},
$$

where $\rho_{0}$ is the density of anhydrous wood,

$$
\rho_{0}=\frac{\rho_{10 \%}}{1.1-0.84 * \rho_{10 \%}} ; \rho_{10 \%}
$$

is the wood density determined at momentary humidity (which is the average humidity for the increment core extracted from 10 trees uniformly assigned in each comparative trial) and $\beta_{v}$ is the total volume expansion of the increment cores: $\beta_{v}=28 * \rho_{0}$.

The diameter and the length of the increment cores were measured with the Lintab 5 tree-ring measurement station. The weights were determined using an electronic scale with a $0.01-\mathrm{mg}$ precision.

The data obtained for all the evaluated quantitative features were statistically processed using the STATISTICA version 8.0 software (StatSoft Inc., 2008). The normal distribution was checked with the KolmogorovSmirnov test and Levene's test was used to assess variance homogeneity before applying the Analyses of Variance (ANOVA). The total variance of the analysed traits was separated (NANSON, 2004) into variance components due to trial sites, replication in sites, populations (seed sources) in replications and the (residual) error variance. The variance component analyses and test of components were made according to the statistical model given below:

$$
X_{i j k}=m+\alpha_{i}+\beta_{i(j)}+\gamma_{j(k)}+\alpha \gamma_{i k}+\varepsilon_{i j k}
$$

where:

$\mathrm{m}$ = overall average trait value;

$\alpha_{i}=$ the effects of $i$ sites $(i=1 \ldots a)$;

$\beta_{i(j)}=$ the effects of $j$ replications in $i$ sites $(j=1 \ldots b)$;

$\gamma_{\mathrm{j}(\mathrm{k})}=$ the effects of $\mathrm{k}$ populations in $\mathrm{j}$ replications $(\mathrm{k}=1 \ldots \mathrm{c})$;

$\alpha \gamma_{\mathrm{ik}}=$ the effects of interaction between trial sites and populations (seed sources);

$\varepsilon_{\mathrm{ij}}=$ the random error.

The analysis of variance is adequate for these types of experiments because the traits are normally distributed and the trees belong to the same generation (WHITE et al., 2007). 
The level of significance of differences was established with the Fisher's $(\mathrm{F})$ test and with the multiple t-test with $p<0.05$. Population ranking and their homogeneous groups were determined with the Duncan's test at $p<0.05$.

The Pearson phenotypic correlations between the traits, on the one hand and between these and the geographic gradients (including the ecophysiological latitude) of the seed source origins, on the other hand, were calculated. The ecophysiological latitude (VIERSMA, 1962) was estimated using the formula $\mathrm{Le}=\mathrm{L}+\mathrm{A} / 100$, where: Le = ecophysiological latitude; $\mathrm{L}$ and $\mathrm{A}=$ latitude and altitude, respectively. The latitude is then corrected for altitude in such way that $100 \mathrm{~m}$ difference in altitude is considered to equal a difference of one degree in latitude (BLADA and POPESCU, 2007).

\section{Results}

\section{Radial increment (RI)}

In the Avrig trial, the average value for RI was $4.053 \mathrm{~mm} /$ year. The largest radial increment was registered in the 5-Moldoviţa population (4.533 mm/year), followed by 32-Câmpeni (4.407 mm/year) and 10-Sânmartin (4.395 mm/year). The lowest $\mathrm{RI}$ value was recorded in the 16-Nehoiu population (3.660 mm/year), 17-Nehoiaşu (3.733 mm/year) and 14-Tarcău (3.764 $\mathrm{mm} /$ year). Compared to the general average of the experiment, the 5-Moldoviţa seed stand had a $12 \%$ higher increase, while the value obtained in the 16-Nehoiu population was about $11 \%$ below the average. In this comparative trial, the majority of the seed sources tested presented a larger RI than the averages of the trial originating in the Western Carpathians (42.9\%) and Eastern Carpathians (35.7\%). The population 22-Bistra, originating from the Southern Carpathians and closest to the testing site, ranked as the $6^{\text {th }}$ best performing seed source tested in this location with respect to radial increment.

In the Breţcu trial, the average RI was 4.104 $\mathrm{mm} /$ year. The largest radial increment was registered in 4-Marginea (4.647 mm/year), followed by 27-Beliş (4.362 $\mathrm{mm} /$ year) and 8-Prundul Bârgăului (4.346 mm/year). The lowest increment values were registered in 14Tarcău (3.799 mm/year), 13-Sovata (3.805 mm/year) and 25-Bozovici (3.872 mm/year). The 4-Marginea seed stand achieved a $13 \%$ higher value compared to the average, while the 14-Tarcău population had a $7 \%$ deficit. From the tested seed sources, the ones with RI values above the general average of the trial came mainly from the Eastern Carpathians (55\%), followed by the Western Carpathians (25\%). The population 15-Comandău, which was situated closest to the testing site, only ranked at $10^{\text {th }}$ position for the size of the radial increment in Breţcu. Another population in close proximity to the testing spot, 10-Sânmartin, was situated in the middle of the ranking, at $16^{\text {th }}$ place.

The analysis of variance (Table 2) highlights significant differences $(p<0.01)$ among the studied populations, while no significant differences between the test sites were found. Likewise, very important interpopula-
Table 2. - ANOVA for radial increment and wood characteristics of Norway spruce seed sources over trial sites.

\begin{tabular}{||c|c|c|c|c|c||}
\hline $\begin{array}{c}\text { Source of } \\
\text { variance }\end{array}$ & $\begin{array}{c}\text { Sum of } \\
\text { squares }\end{array}$ & DF & $\begin{array}{c}\text { Mean } \\
\text { square }\left(\mathbf{s}^{2}\right)\end{array}$ & $\mathbf{F}_{\text {value }}$ & p \\
\hline \multicolumn{7}{|c||}{ Radial increment } \\
\hline Trial site & 0.58 & 1 & 0.58 & 2.18 & 0.1405 \\
\hline Replication & 5.21 & 2 & 2.61 & $9.8^{* * *}$ & 0.0001 \\
\hline Seed source & 15.66 & 35 & 0.45 & $1.69^{* *}$ & 0.0092 \\
\hline $\begin{array}{c}\text { Trial site } x \\
\text { seed source }\end{array}$ & 9.83 & 35 & 0.28 & 1.06 & 0.4373 \\
\hline Error & 152.03 & 574 & 0.265 & & \\
\hline \multicolumn{7}{|c|}{ Latewood percentage } \\
\hline Trial site & 30769.9 & 1 & 30769.9 & $631^{* *}$ & 0.0000 \\
\hline Replication & 3797.0 & 2 & 1898.5 & $39^{* * *}$ & 0.0000 \\
\hline Seed source & 3769.1 & 35 & 107.7 & $2.21^{* * *}$ & 0.0001 \\
\hline $\begin{array}{c}\text { Trial site } x \\
\text { seed source }\end{array}$ & 2764.8 & 35 & 79.0 & $1.68^{*}$ & 0.0442 \\
\hline Error & 26916.97 & 574 & 46.89 & & \\
\hline \multicolumn{7}{|c|}{ Wood density } \\
\hline Trial site & 0.0578 & 1 & 0.058 & $127^{* * *}$ & 0.0000 \\
\hline Replication & 0.0022 & 2 & 0.001 & 2.4 & 0.0908 \\
\hline Seed source & 0.0344 & 35 & 0.001 & $2.17^{* * *}$ & 0.0002 \\
\hline $\begin{array}{c}\text { Trial site } x \\
\text { seed source }\end{array}$ & 0.0158 & 35 & 0.0005 & 1.0 & 0.4863 \\
\hline Error & 0.2604 & 574 & 0.0005 & & \\
\hline
\end{tabular}

$\mathrm{DF}=$ Degrees of freedom. ${ }^{*} \mathrm{p}<0.05,{ }^{* *} \mathrm{p}<0.01,{ }^{* * *} \mathrm{p}<0.001$.

tional differences $(p<0.05)$ resulted applying ANOVA for every 5 years periodical RI, excepting the 2006-2010 interval.

The Duncan's test with $p<0.05$ revealed five homogeneous groups for the populations tested in Avrig, and only two groups in Breţcu. All the populations included in the most valuable homogeneous group displayed RI values above the average of the experiment.

The analysis of the radial increment coefficient of variation at the tree level and then as the population average allowed the identification of some populations whose radial increments were relatively uniform. We expected to identify such populations in the Eastern Carpathians, which is considered to be the optimal area for the Carpathian race of Norway spruce (STĂNESCU et al., 1997). This was confirmed in Breţcu, where the most steady increment rhythm was accomplished by populations 8-Prundul Bârgăului and 4-Marginea ( $\mathrm{s} \%=36 \%)$, closely followed by 5-Moldoviţa $(\mathrm{s} \%=37 \%)$, 7-Năsăud and 12 -Gurghiu $(\mathrm{s} \%=39 \%)$. The highest variations for radial increments from one year to another was observed for 23 -Voineasa $(\mathrm{s} \%=55 \%)$, which came from the highest altitude $(1400 \mathrm{~m})$ and originating from the Southern Carpathians. Outside of the natural area for Norway spruce, in Avrig, populations with the smallest coefficients of variation of annual radial increments originated from various Carpathian areas: Southern Carpathians (24-Retezat, s\%=36\%), Western Carpathians (25-Bozovici, s\% $44 \%)$ or Eastern Carpathians (1-Coşna, s\%=44\%). In this trial, the highest values of the coefficients of variation of annual radial increments had some populations originating from Eastern and 
Western Carpathians (10-Sânmartin and 16-Nehoiu, s\% $=57 \%$, followed by 17-Nehoiaşu, 19-Azuga and 27Beliş, all of them with s\% $=55 \%$ ).

\section{Latewood percentage (LWP)}

Latewood favorably influences certain properties of wood and wood products, as well as cellulose paste (DUMITRIU-TĂTĂRANU et al., 1983).

In Avrig, latewood represented an average of $24 \%$ of the total radial increment, having a rather large amplitude of variation, from $31.1 \%$ (5-Moldoviţa) to $16.8 \%$ (30-Dobreşti). Besides the population 5-Moldoviţa, the 6Stulpicani (30.3\%) and 17-Nehoiaşu (28.5\%) populations also belonged to the first class of variation, all originating from the Eastern and Curvature Carpathians. The populations with the lowest proportion of latewood (30Dobreşti, $16.8 \%$ and 28-Turda, $17.9 \%$ ) originated from the Western Carpathians.

In Breţcu, latewood represented an average of $38 \%$ of the mean value of RI. Similar to Avrig, the highest percentage of latewood was recorded in the populations of the Eastern Carpathians (6-Stulpicani, 43.1\%, 7Năsăud, 42.2\% and 5-Moldoviţa, 42.1\%), and the lowest in those from the Western Carpathians (32-Câmpeni, $30.6 \%$, 31-Sudrigiu, 31.8\% and 30-Dobreşti, 34.0\%).

The ANOVA test (Table 2) indicated the existence of highly significant differences $(p<0.001)$ among the populations, and between test sites and replications, which suggest a very important environmental influence and an important genetic influence. The significant value $(p<0.05)$ for locations $\mathrm{x}$ populations interaction suggests that several populations may score an increase or decrease of the latewood percentage from one location to another. By applying Duncan's test with $p<0.05$, we observed a large number of homogeneous groups of populations (six in Avrig and eight in Breţcu).

In both sites, the provenances with the closest origin to the test site were situated in the bottom half of the ranking: $20^{\text {th }}$ position in Avrig for 22-Bistra, and positions 17 and 22 in Breţcu for 15-Comandau and 10-Sînmartin, respectively.

Review of the latewood dynamics for every 5-year interval allowed the formulation of the following findings:

In Avrig, the population 5-Moldoviţa (Eastern Carpathians), designated in 1996 by I.U.F.R.O. as a standard provenance, presented the highest latewood percentage in 4 out of 5 periods, excepting the interval 1996-2000, when it was ranked $3^{\text {rd }}$ out of the 33 tested seed sources. In Breţcu, the population 4-Marginea (Eastern Carpathians), whose genetic value was demonstrated in international studies (UJVARI and UJVARI, 2006), occupied first place in 3 out of 5 periods (the interval 1986-2000) and second place in the 1991-1995 period for the latewood percentage. In both trials other seed sources with high latewood percentages in all the 5 -year periods also originated from the Eastern Carpathians (eg 8-Prundul Bârgăului and 6-Stulpicani) and with low latewood percentages at each 5-year period originated from Western Carpathian (eg. 28-Turda, 29Beiuş and 30-Dobreşti, 32-Câmpeni, 31-Sudrigiu).

\section{Conventional wood density (CWD)}

In Avrig, the average value of CWD was $0.348 \mathrm{~g} / \mathrm{cm}^{3}$. The amplitude of variation among the average values of the tested populations was low, only $0.039 \mathrm{~g} / \mathrm{cm}^{3}$; therefore, the value of the coefficient of variation was also very low $(2.87 \%)$. The following populations were placed in the first class of values with the highest wood density: 11-Topliţa $\left(0.366 \mathrm{~g} / \mathrm{cm}^{3}\right), 24-R e t e z a t ~\left(0.363 \mathrm{~g} / \mathrm{cm}^{3}\right)$, as well as 22-Bistra, 17-Nehoiaşu and 16-Nehoiu (each with $\left.0.359 \mathrm{~g} / \mathrm{cm}^{3}\right)$. The lowest value was found in 5Moldoviţa $\left(0.327 \mathrm{~g} / \mathrm{cm}^{3}\right)$, followed by 12 -Gurghiu $(0.329$ $\left.\mathrm{g} / \mathrm{cm}^{3}\right)$ and 32-Câmpeni $\left(0.335 \mathrm{~g} / \mathrm{cm}^{3}\right)$. Applying the $\mathrm{t}$ multiple test resulted significant differences $(p<0.05)$ between the populations from the top and bottom of the ranking, mentioned above. The populations with high radial increments had, as expected, low values of conventional density. The lowest value found in the 5Moldoviţa population, which registered the largest radial increments in this comparative trial, was persuasive in this sense. There was a difference of 5 to $6 \%$ among the populations situated at the extremes of the ranking and the experiment average. The local origin (22-Bistra) was ranked $3^{\text {rd }}$ in Avrig.

In Breţcu, the average value of CWD was $0.329 \mathrm{~g} / \mathrm{cm}^{3}$, $5.8 \%$ lower than the average value in Avrig. By comparing the populational averages, there was also a low amplitude of variation, only $0.036 \mathrm{~g} / \mathrm{cm}^{3}$, so the coefficient of variation had a similar value to the one determined in Breţcu (2.74\%). The populations with the highest values for wood density were: 17-Nehoiaşu $(0.350$ $\left.\mathrm{g} / \mathrm{cm}^{3}\right), 24$-Retezat $\left(0.341 \mathrm{~g} / \mathrm{cm}^{3}\right)$ and 29 -Beiuş and 14 Tarcău (both with $0.340 \mathrm{~g} / \mathrm{cm}^{3}$ ). At the opposite end were 12-Gurghiu, 9-Rodna and 31-Sudrigiu, each with 0.314 $\mathrm{g} / \mathrm{cm}^{3}$. A relationship between the density and the size of radial increment was also noticed in this trial. For example, 14-Tarcău ranked last according to the radial increments, but ranked third in decreasing order according to the conventional density. The populations closest to the testing site, 15-Comandău and 10-Sânmartin, displayed density values similar to the experiment average, placing themselves in the most valuable homogeneous group.

Highly significant differences among populations and between test sites (Table 2) were recorded. The populations $\mathrm{x}$ site interaction was no significant suggesting that the populations show stable performances across the test sites.

\section{Correlation analysis}

The RI was positively and highly significantly correlated with earlywood $\left(\mathrm{r}=0.75^{* * *}\right.$ in Avrig, $\mathrm{r}=0.68^{* * * *}$ in Breţcu) and latewood ( $\mathrm{r}=0.44^{* * *}$ in Avrig, $\mathrm{r}=0.66^{* * * *}$ in Breţcu), and negatively and highly significantly with wood density $\left(\mathrm{r}=-0.21^{* * * *}\right.$ in Avrig, $\mathrm{r}=-0.33^{* * *}$ in Breţcu) - Table 3 .

Regarding the interdependence between the width of annual rings and the ecological gradients of the stand's origins, there was a direct and significant correlation with latitude only in Breţcu, but not confirmed in Avrig trial.

In Breţcu, the amount of latewood correlated highly significant with latitude $(\mathrm{r}=0.20 * * *)$, clearly signifi- 
Table 3. - Phenotypic correlations between radial increment, wood characteristics and geographic gradients of the Norway spruce seed sources origin.

\begin{tabular}{|c|c|c|c|c|c|c|c|c|}
\hline Variables & Earlywood & Latewood & $\begin{array}{l}\text { Latewood } \\
\text { percentage }\end{array}$ & $\begin{array}{l}\text { Wood } \\
\text { density }\end{array}$ & $\begin{array}{l}\text { Latitude } \\
\text { (N) }\end{array}$ & $\begin{array}{c}\text { Ecophysiologica } \\
\text { latitude }\end{array}$ & $\begin{array}{c}\text { Longitude } \\
\text { (E) }\end{array}$ & Altitude \\
\hline \multicolumn{9}{|c|}{ Comparative trial AVRIG } \\
\hline $\begin{array}{c}\text { Radial } \\
\text { increment }\end{array}$ & $0.75^{* * *}$ & $0.44 * * *$ & 0.07 & $-0.21 * * *$ & 0.00 & 0.01 & -0.1 & 0.01 \\
\hline Earlywood & - & $-0.27 * * *$ & $-0.60 * * *$ & $-0.28 * * *$ & -0.02 & -0.04 & $-0.20 * * *$ & -0.04 \\
\hline Latewood & & - & $0.92 * * *$ & 0.08 & 0.03 & 0.07 & $0.13^{*}$ & 0.06 \\
\hline $\begin{array}{c}\text { Latewood } \\
\text { percent }\end{array}$ & & & - & $0.17 * *$ & 0.02 & 0.08 & $0.19^{* *}$ & 0.07 \\
\hline $\begin{array}{c}\text { Wood } \\
\text { density }\end{array}$ & & & & - & $-0.12 *$ & -0.07 & 0.06 & -0.02 \\
\hline \multicolumn{9}{|c|}{ Comparative trial BREȚCU } \\
\hline $\begin{array}{c}\text { Radial } \\
\text { increment }\end{array}$ & $0.68 * * *$ & $0.66^{* * *}$ & $0.20^{* * *}$ & $-0.33 * * *$ & $0.14 *$ & 0.05 & 0.04 & -0.01 \\
\hline Earlywood & - & -0.10 & $-0.60 * * *$ & $-0.37 * * *$ & -0.03 & -0.02 & -0.10 & 0.00 \\
\hline Latewood & & - & $0.80^{* * *}$ & -0.07 & $0.23 * * *$ & 0.09 & $0.16^{* *}$ & -0.01 \\
\hline $\begin{array}{c}\text { Latewood } \\
\text { percent }\end{array}$ & & & - & $0.13^{*}$ & $0.20 * * *$ & 0.08 & $0.17^{* *}$ & 0.00 \\
\hline $\begin{array}{l}\text { Wood } \\
\text { density }\end{array}$ & & & & - & $-0.12 *$ & $-0.14 *$ & 0.03 & -0.09 \\
\hline
\end{tabular}

${ }^{*} \mathrm{p}<0.05 ;{ }^{* *} \mathrm{p}<0.01 ;{ }^{* * *} \mathrm{p}<0.001$.

cantly with longitude $\left(\mathrm{r}=0.17^{* *}\right)$ and not significant with ecophysiological latitude $(r=0.08)$, which explains the differences recorded between populations from different regions of study area. Thus, in both locations, the highest values were recorded in seed sources originating from the Eastern Carpathians, while the lowest values were from those in the Western Carpathians, in their northern branch represented by the Apuseni Mountains. However, in the trial outside the natural range, LWP did not reveal any correlation with latitude or ecophysiological latitude. Unlike latewood, spring increments were influenced mostly by longitude, the values decreasing from west to east. However, an influence of longitude $\left(\mathrm{r}=-0.20^{* * *}\right)$ was recorded only in the area located outside the natural range of Norway spruce. As expected, in both sites earlywood is negatively correlated with the wood density, but with a slightly higher intensity in the test installed in the natural range $(\mathrm{r}=-0.28 * * *$ in Avrig, and $\mathrm{r}=-0.37 * * *$ in Breţcu). On the other hand, in Breţcu, the proportion of latewood positively and highly significant correlated with latitude and clearly significant with longitude. In Avrig, the correlation was also positive, but the significance level was lower for latitude, while for longitude correlation was also clearly significant.

The correlations between CWD and latitude or ecophysiological latitude are negative but in very low intensity (Table 3). Therefore, they cannot be used as selection criteria for identifying valuable seed sources.This correlation type was also reported in other works conducted in spruce in Romania (STĂNESCU et al., 1997).

\section{Discussion}

The preponderance of populations with $\mathrm{RI}$ values higher than the overall average originating from the
Eastern and Western Carpathians confirm the superiority of their gene pool compared to those from the Southern Carpathians. This has also been observed in other studies done in comparative trials in Romania (ENESCU and IONIŢĂ, 2002; MIHAI, 2009).

The dynamics of RI values was similar for all populations. The highest one was recorded around the age of 10 to 15 years. Compared to the average RI for the 30 years of tests, the maximum periodic average increment for a 5-year interval was $45 \%$ higher in Avrig and $42 \%$ in Breţcu. Populations from the Eastern and Western Carpathians were in the top of the rankings, while those from the Southern Carpathians showed a lower growing rate. Moreover, certain populations (i.e., 4-Marginea and 5-Moldoviţa) displayed a higher increment during all the analyzed 5-year periods. However, other populations yielded lower RI values for the first periods, but this increased in the last decade (i.e., 24-Retezat). A strong decrease of RI was recorded in the last decades for some populations (e.g. 10-Sânmartin in Avrig and 23-Voineasa and 14-Tarcău in Breţcu). Such situations of periodical fluctuations in RIs can modify the population ranking established at a certain moment. For this reason, to get more conclusive data, research should continue in these comparative trials after 30 years of age. However, the selection for growth and wood characteristics it's possible at this age, as resulted in other type of experiments (YILDIRIM et al., 2011).

Due to the big differences among populations, genetic gain can be improved by switching to advanced generations of selection (KLAPSTE et al., 2007). Indeed, both trial sites exhibited high values of intrapopulational variability. This can be used in future breeding programs, including the selection of some valuable genitors that do not belong to the populations with the highest potential of RI. 
Considering the quantum of RI, the fact that the populations did not represent homogenous groups with regard to their geographical location attests their phenotypic divergence, even when they originate from the same region. In this context, testing the seed sources in multisite comparative trials proved to be really useful. In fact, divergent results in various site conditions of the same type of biological material have been observed for Norway spruce in several studies (ENESCU, 1996; RAISKILA et al., 2006; MiHAI, 2009). The average differences between the annual RI values in each of the 33 populations in the two trials were $0.188 \mathrm{~mm}(4.7 \%)$. The RIs were higher in Breţcu than in Avrig by about $67 \%$ of the evaluated seed sources. Most of them (64\%) originated from the Eastern and Curvature Carpathians. In fact, only $17.6 \%$ of the seed sources originating from this area achieved lower average RIs in Avrig, which is outside the natural distribution range for Norway spruce. The largest difference between the two experiments was recorded for 4-Marginea (Eastern Carpathians), which had a $22 \%$ higher value in Breţcu than in Avrig. The smallest differences between the two test locations were observed for 8-Prundul Bârgăului (Eastern Carpathians) and 28-Turda (Western Carpathians), both with only a $0.1 \%$ higher radial average increment in Breţcu.

The increment rate for Norway spruce can be considered an effective way of predicting wood density (SKRØPPA and DIETRICHSON, 1999). Smaller radial increments generate superior values of wood density (BLOUIN et al., 1994). A negative influence of temperature and precipitation variation on radial increment from the second half of the growing season was reported by BOURIAUD et al. (2005), while a reduction of radial increments increased wood density because of summer wood production. Our correlative analysis for RI, LWP and CWD in the two sites indicates likewise the influence of temperature and precipitation recorded during the growing season. Thus, on the one hand, the precipitation amount is higher in Avrig by about $15 \%$. On the other hand, in Breţcu trial, which has a higher altitude of about $500 \mathrm{~m}$ than Avrig, the average temperature is lower by $6.3 \%$ in the first two months of the growing season, respectively by $4.5 \%$ in last two months. In these circumstances, in the Breţcu trial the mean values are smaller for CWD but higher for LWP. The LWP was higher in Breţcu for all seed sources tested, the overall average difference between population values of the two comparative trials being $59.3 \%$. The highest differences resulted for the Western Carpathian populations, on average $68.9 \%$.

The low values of coefficients of variation for radial increment for many populations from the Eastern Carpathians may be due to the existence of Norway spruce with resonance wood in that part of Romania. Recent research carried out in Eastern Carpathians concerning Norway spruce resonance wood characteristics for the musical instrument industry (ALBU, 2010) showed that its formation began at the age of 30 years, where the rings have a width of up to 2.5 to $3.5 \mathrm{~mm}$. Also, the trees belonging to this biotype are characterized by a highly uniform annual ring width (up to $40 \%$ for the rings regularity index) and the proportion of late- wood not exceeding $30 \%$ of the total width of the annual rings. Such trees with potential for resonance wood were identified in the progenies of trees originating from the populations 1-Coşna and 3-Frasin (Eastern Carpathians), in Breţcu trial. Furthermore, the selection of biotypes with the appropriate characteristics for resonance wood can be one of the auxiliary objectives for consideration in further evaluations that will be made in these comparative trials.

Comparative analysis of LWP values revealed obvious differences between the two sites (24.2\% in Avrig and $37.9 \%$ in Breţcu). The LWP was higher in Breţcu for all seed sources tested, the overall average difference between population values of the two comparative trials being $59.3 \%$. The highest differences resulted for the Western Carpathian populations, on average $68.9 \%$. The higher values registered in Brețcu could be explained from the perspective of its location within the natural distribution range of Norway spruce, which has a higher altitude of about $500 \mathrm{~m}$ than Avrig. In these circumstances, there are climatic differences between the two sites that could explain the different values for LWP. For example, in Breţcu trial the average temperature in the first two months of the growing season is lower by $6.3 \%$ than Avrig and this can reduce the amount of earlywood. At the same time, seed sources that were tested were located mostly in the mountainous areas, while Avrig is located outside of Norway spruce's natural range, in a pre-mountainous fitoclimatic region.

The smallest differences between the two trials regarding LWP were recorded in 32-Câmpeni (an extra $4.5 \%$ in Breţcu), followed by 31-Sudrigiu (an extra $6.1 \%$ in Breţcu), while the largest differences were in 27-Beliş (an extra $19.9 \%$ in Breţcu), followed by 29-Beiuş (an extra $19.7 \%$ in Breţcu). Higher values of latewood percentages for Nordic provenances were also reported by SKRøPPA and DIETRICHSON (1999) in a test with 15 provenances from Norway.

Similar results to those from the Avrig trial were recorded by ZuBIZARRETA GERENDIAIN et al. (2007, 2008) for a stand located in southeast Finland at an altitude of $60 \mathrm{~m}$, where the latewood percentage was between 18 and $26 \%$. Mirna (2000) obtained an average of $24 \%$ for the latewood percentage in a natural stand in eastern Finland, while MÄKINEN et al. (2002) reported an average of $20 \%$. In Romania, in a Southern Carpathian population located at about $1000 \mathrm{~m}$ in altitude, STĂNESCU and ŞofletEA (1992) observed an average latewood proportion of about $19 \%$.

Regarding CWD, due to the very small differences among the populations within the same location, the coefficients of variation were only $2.87 \%$ in Avrig and $2.74 \%$ in Breţcu. Our results are consistent with those from the literature (GINDL et al., 2000; JYSKE et al., 2008), which also demonstrate a low level of interpopulational variability of wood density. However, the ANOVA test revealed significant differences among populations. Moreover, the values measured for this wood trait were similar to those reported in other studies in Romania (DUMITRIU-TĂTĂRANU et al., 1983; StăNESCU 
and ŞofleteA, 1992; PÂRnUŢă, 2008). In Norway, Hylen (1997) recorded values that were smaller by $13.8 \%$ of the Avrig trial average value and $8.8 \%$. In Finland, a 20year old comparative clonal trial indicates an average density of about $0.36 \mathrm{~g} / \mathrm{cm}^{3}$ (ZuBIZARRETA GERENDIAIN et al., 2009). This value is higher than the one from our study and that of HYLEN (1997). Higher values of wood density for northern provenances were also observed in a 15-provenance test conducted in Norway by SKRøPPA and DIETRICHSON (1999).

Considering that wood density is under strong genetic control, but ring width and proportion of latewood are with low heritability (ZHANG and JIANG, 1998), selection related to this trait becomes more important. Except one population from the Eastern Carpathians (5-Moldoviţa), all the other populations displayed lower wood density values in Breţcu, in the natural range of Norway spruce. For this trait, the average difference demonstrated between the two sites was $5.8 \%$, without any notable differences related to the population's origin. A previous study conducted in Romania (STĂNESCU and ŞOFLETEA, 1992) for two field tests located at altitudes of 1040 and $1400 \mathrm{~m}$ revealed similar results.

\section{Conclusions}

Concerning the Norway spruce populations from the Romanian Carpathians, the data analysis from two locations regarding RI and LWP showed a large interpopulational variability, while for wood density, the variability was lower; intrapopulational variability was also high, these results suggesting that the selection of the most valuable trees from the most valuable populations could be possible and lead to a higher genetic gain.

Regarding RI, the best performances were recorded for the populations from the Eastern Carpathians and Apuseni Mountains, while the Southern Carpathian provenances exhibited a lower increment potential. Summing the data from the two sites, one located outside the natural range of Norway spruce (Avrig) and the other in its ecologically optimum range (Breţcu), the largest RI was recorded in the population 27-Beliş, originating from the Apuseni Mountains, followed by 8-Prundul Bârgăului, 32-Câmpeni, 5-Moldoviţa and 10-Sânmartin.

The highest LWP values were recorded for the populations that were native to the Eastern Carpathians, 95\% of them being assigned to the most valuable homogeneous group. At the opposite end, there were the populations from the Western Carpathians. The differences between these two Carpathian branches are part of a gradient variation model characterized by a slight increase in LWP from west to east. On the other hand, although the differences between the RI means at the two sites were relatively small, there were increases for LWP, for which the values were clearly lower outside the natural area of Norway spruce.

The CWD was higher by $5.8 \%$ in a pre-mountainous region outside the natural range of Norway spruce, confirming the results from previous studies about a discrete trend of reverse variation with latitude and cor- rected latitude in the Carpathians. High values for this quantitative trait of wood in both locations were recorded in 17-Nehoiaşu, 24-Retezat and 11-Topliţa populations.

Taking into account published data (ENESCU and IONIŢĂ, 2002), we observed that when the trees became older, the amplitude of variation of the different increment and wood traits became larger, leading to changes in the population rankings over time. This will require further periodic evaluations at these sites after age of 30 of trees.

Regarding the examined traits and analyzing the behavior of populations at both sites, we can conclude that the most stable populations were 8-Prundul Bârgăului, 20-Domneşti, 19-Azuga, 21-Orăştie, 14Tarcău, 17-Nehoiaşu and 32-Câmpeni. The first and last population above filled the top positions in the rankings for RI. The 16-Nehoiu population also stood out by its high values of wood density.

\section{Acknowledgements}

This paper is financed by the National Forest Administration (ROMSILVA) in the frame of ROMSILVA Research Programme, contracted with Forest Research and Management Institute.

We wish to thank to Dr. LUCIA IONIŢĂ for providing the necessary documentation and to our devoted colleagues: Dan PePelea, CătĂLin CoJANu and GRUiţĂ IENĂŞOIU for their help in the field measurements. We would like to thank also to Academic Proofreading Services (England) for polishing the English text.

The authors express their gratitude to anonymous reviewers for their important contribution in the manuscript improvement.

\section{References}

AlBU, C. T. (2010): Cercetări privind caracteristicile lemnului de molid de rezonanţă în bazinul râului Gurghiu (Ocoalele silvice Gurghiu şi Fâncel), în concordanţă cu solicitările industriei instrumentelor muzicale. Teză de doctorat, Universitatea Transilvania din Braşov, România.

Alexandrov, A. and T. Stankova (1997): Norway spruce provenance trials in Bulgaria. IUFRO Norway spruce symposium, Stara Lesna, Slovakia, 8p.

BADEA, O. (2008): Manual privind metodologia de supraveghere pe termen lung a stării ecosistemelor forestiere aflate sub acţiunea poluării atmosferice şi modificărilor climatice. Editura Silvică, Bucureşti.

BladA, I. and F. Popescu (2007): Swiss Stone Pine Provenance Experiment in Romania II: Variation in Growth and Branching Traits to age 14. Silvae Genetica 56(3-4): 148-158.

Blouin, D., J. Beaulieu, G. Daoust and J. Poliquin (1994): Wood quality of Norway spruce grown in plantations in Quebec. Wood and Fiber Science 26(3): 342-353.

Bouriaud, O., J.-M. Leban, D. Bert and C. Deleuze (2005): Intra-annual variations in climate influence growth and wood density of Norway spruce. Tree Physiology 25: 651-660. 
Dutcă, I., I. V. Abrudan, P. T. StĂNCIOIU and V. BlujdeA (2010): Biomass Conversion and Expansion Factors for Young Norway Spruce (Picea abies (L.) Karst.) Trees Planted on Non-Forest Lands in Eastern Carpathians. Notulae Botanicae Horti Agrobotanici Cluj-Napoca, vol. 38, Issue 3: 286-292.

Dumitriu-TĂtĂRANu, I., N. Ghelmeziu, I. Florescu, I. Milea, V. Moş and M. Tocan (1983): Estimarea calităţii lemnului prin metoda carotelor de sondaj. Editura Tehnică, Bucureşti.

ENESCU, V. (1996): Variabilitatea genetică inter şi intrapopulaţională pe bază de culturi comparative multistaţionale de descendenţe materne de molid. Referat Științific Final, Manuscris I.C.A.S. București.

ENESCU, V. and L. IONIŢĂ (2002): Variaţia genetică inter şi intrapopulațională a unor resurse genetice de molid (Picea abies (L) Karst.). Annals of Forest Research 45: 67-77.

GIERTYCH, M. (1984): Report on IUFRO 1938 and 1939 provenance experiments on Norway spruce, Polish Academy of Sciences. Institute of Dendrology, Kornic.

GIERTYCH , M. (1993): Breeding Norway spruce in Poland: from provenance tests to seed orchards, Norway spruce provenances and breeding. Proceedings of IUFRO (S2.211) Symposium, Latvia, 193-199.

GindL, W., M. GRABNER and R. Wimmer (2000): The influence of temperature on latewood lignin content in treeline Norway spruce compared with maximum density and ring width. Trees 14: 409-414.

Hylen, G. (1997): Genetic variation of wood density and its relationship with growth traits in young Norway spruce. Silvae Genetica 46(1): 55-60.

IoRAS, F. and I. V. ABRUDAN (2006): Romanian forestry sector-privatization facts. The International Forestry Review 8(3): 361-367.

Jyske, T., H. MAKINEN and P. SARANPAA (2008): Wood density within Norway spruce stems. Silva Fennica 42(3): 439-455.

KARLSSON, B. and K.-A. HogBerg (1998): Genotypic parameters and clone $\mathrm{x}$ site interaction in clone tests of Norway spruce. Forest Genetics 5: 21-30.

KLAPSTE, J., M. LstibUREK and J. KoBliHa (2007): Initial evaluation of half-sib progenies of Norway spruce using the best linear unbiased prediction. Journal of Forest Science 53(2): 41-46.

KonIG, A. O. (2005): Provenance research: evaluating the spatial pattern of genetic variation, pp. 284-290. In: Conservation and Management of Forest Genetic Resources in Europe, edited by Thomas Geburek and Josef Turok , Arbora Publishers, Zvolen.

KRUTZSCH, P. (1992): IUFRO s Role in Coniferous Tree Improvement: Norway Spruce (Picea abies (L) Karst.). Silvae Genetica 41(3): 143-150.

MÄKINEN, H., P. SARANPÄÄ and S. LINDER (2002): Wooddensity variation of Norway spruce in relation to nutrient optimization and fibre dimensions. Canadian Journal of Forest Research 32: 185-194.

MATRAS, J. (1997): Growth and plasticity of Norway spruce population in IUFRO 1972 experiment, IUFRO Norway spruce symposium. Stara Lesna, Slovakia.

MiHAI, G. (2009): Surse de semințe testate pentru principalele specii de arbori forestieri din România. Editura Silvică, București.

MiINA, J. (2000): Dependence of tree-ring earlywood and latewood indices of Scots pine and Norway spruce on climatic factors in eastern Finland. Ecological Modelling 132: 259-273.
NANson, A. (2004): Génétique et amélioration des arbres forestières. Les presses agronomique de Gembloux.

NAAPOLA, M. L. (1997): The growth and adaptation of the IUFRO 1964/1968 Norway spruce provenance material in Finland, IUFRO Norway spruce Symposium. Stara Lesna, Slovakia.

PÂRNUŢĂ, G. (2008): Variabilitatea genetică şi ameliorarea arborilor de molid cu coroană îngustă în România. Editura Silvică, București.

PÂrnuţă, G., A. Lorenţ, M. Tudoroiu and M. Petrila (2010): Regiuni de provenienţă pentru materiale de bază din care se obţin materiale forestiere de reproducere în România. Editura Silvică, București.

PÂrnuţă, G., E. Stuparu, M. Budeanu and V. ScărLĂTESCU (2011): Catalogul Naţional al resurselor genetice forestiere. Editura Silvică, Bucureşti.

Raiskila, S., P. SARANPäÄ, K. Fagerstedt, T. LAAKSO, M. LÖIJA, R. MAHLBERG, L. PAAJANEN and A.-C. RitschKofF (2006): Growth rate and wood properties of Norway spruce cutting clones on different sites. Silva Fennica 40(2): 247-256.

Skrøppa, T. and J. Dietrichson (1999): Relationships between wood density components and juvenile height growth and growth rhythm traits for Norway spruce. Silvae Genetica 48(5): 235-239.

SkRøPPA, T. (2005): Ex situ conservation methods, pp. 567-583. In: Conservation and management of forest genetic resources in Europe, edited by THOMAS GEBUREK and Josef TURoK , Arbora Publishers, Zvolen.

StĂNescu, V. and N. ŞofleteA (1992): Cercetări de genetică ecologică în molidişuri montane (II). Revista Pădurilor 1: 2-5.

Stănescu, V., N. Şofletea and O. Popescu (1997): Flora forestieră lemnoasă a României. Editura Ceres, Bucureşti.

UJVARI, E. and F. Ujvari (2006): Adaptation of progenies of a Norway spruce provenance test (IUFRO 1964/68) to local environment. Acta Silvatica Lignignaria Hungarica 2: $47-56$.

VIERSMA, J. H. (1962): Enkete kwantitatiere aspecten van het exotenvraagstuk. Hederlareds Bosbonw Tiytschrift 34 (5): 175-184.

White, T.W., W.T. Adams and D. B. Neale (2007): Forest genetics. CAB International, CABI Publishing, Cambridge.

YILDIRIM, K., H. ÖZTÜRK, S. ŞIKLAR, D. B. ÖZGÜR and Z. KAYA (2011): Strong genetic control of high wood specific gravity in young progenies of Pinus brutia: Potential of early selection for industrial plantations. Silvae Genetica 60(6): 249-258.

ZHANG, S. Y. and Z. H. JIANG (1998): Variability of selected wood characteristics in 40 half-sib families of black spruce (Picea mariana). Wood Science and Tehnology 32: 71-82.

Zubizarreta Gerendiain, A., H. Peltola, P. Pulkkinen, R. JAATinen, A. PAPPinen and S. KellomäKI (2007): Differences in growth and wood property traits in cloned Norway spruce (Picea abies). Canadian Journal of Forest Research 37: 2600-2611.

Zubizarreta Gerendiain, A., H. Peltola, P. Pulkkinen, R. JAATinen and A. PAPPINEN (2008): Differences in fibre properties in cloned Norway spruce (Picea abies). Canadian Journal of Forest Research 38: 1071-1082.

Zubizarreta Gerendiain, A., H. Peltola and P. PulkkiNEN (2009): Growth and wood property traits in narrow crowned Norway spruce (Picea abies f. pendula) clones grown in southern Finland. Silva Fennica 43(3): 369-382. 